が急峻なので，極めて小さなディテクターがないと，十分な空間分 解能で線量剆定できない.そこで実测を好きにしていきなり線量分 布計算をすることが先行した分野を敢えて演者はチャレンジし，治 療計画装置の計算精度 (PLATO-BPS) が踟床応用可能と結論づけ た. 自信をもって䠛床に望む姿勢に敬意を表する．以上，4人の演 者の放射線治療に対する熱心さに感銘するとともに,特定の施設だ けでいくら治療成績をあげても,放射線治療の発展につながらない ことを我々は自覚し，日々研鑍したい。そのためにも，汎用性・実 用性のある放射線治療技術のデータベースの構築が急がれる.

\section{放射線管理 付加フィルタ（演題番号89〜93）}

藤本信久 (京都医療技術短期大学) 近年, 被曝低減への関心が高まる中で，付加フィルタに関する研 究発表が増加しつつあることは好ましいことである.しかし、ここ で問題となるのは, 付加フィルタの効果を言価する場合の評価方法 に，現在のところ統一性がほとんどないため，研究者間での相互比 較が困難となる点である。例えば発表の中でも，被曝線量の指標と して表面線量で評価したグループと, 線量当量で評価したグループ があった。この点について意見交換を行ったが，フィル夕の付加に よるX線の散乱状態の変化等を考慮すると, 表面線量を実測するこ とは重要であると考えられる。ただし，評価基準としてどのような 線量を採用するべきかについては，さらに議論が必要である。ま た, 测定器および测定方法についても, 今後の課題として検討して いく必要がある。

フィルタの効果を議論する上で, 線量評価と同時に画質の評価が 重要となるが、ここにもある程度の一般性が必要であると考えられ る.この点に関して, 津坂 (名大医短) からコントラスト評価の必 要性について，意見が述べられた，画質をある程度定量的に評価し た上での線量評価が必要となるであろう。

最近の傾向として, 希土類元素をはじめとする種々の材料を，フ イルタとして使用した場合の報告が増加している.この中で，フィ ルタ材料を選択する場合の理論的根挑について, 西谷 (京都医短) から質問があった，フィルタの効果としては，低エネルギーX線の 除去と吸収端の利用が考えられるが、これらを十分考慮したフィル 夕の選択が必要となる，また，フィル夕から発生する特性X線およ び散乱X線の影響にも，考慮が必要とされることが, 発表の中から 示睃された。

また, 最近の研究の特徴として, Ge 半導体検出器や $\mathrm{TeCd}$ 検出器 を使用してX線スペクトルを計測し，これをフィルタの特性解析に 利用する方法が採用されつつある. TeCd 検出器のレスポンス補正 について星野（結核研究所）から質問があった。 TeCd 検出器の場 合レレスポンス補正による低エネルギー部分でのスペクトル形状の 変化が顥著であるため, 補正は必須であると共に, 適正な補正計算 の実施が必要される。

計算機シミュレーションも含めて, X線スペクトルを利用した解 析方法は, フィル夕効果解析の有効な手段として, 今後の発展が期 待されるものである。

検査部位, 方法, 目的等によって最適なフィル夕は変化する上考 えられる。この場合に,フィル夕交換の自動化が実現できれば，フ ィル夕使用の促進に有効であることは事実である。この点に関する 装置メーカへの期待が粟井（国立䀠環器）より発言された。

最後に, 本田（東芝）から，被曝低減と同時に画質も改善できる
フィルタの開発を目指している旨の発言があった.フィルタ研究の 今後の指針として期待される。

放射線計測（演題番号94～98）

八木浩史（徳島大学医療技術短期大学部）

演題94は, 透視条件でのエネルギースペクトルを半導体検出器て 測定し，低エネルギー側の補正に「アンフォールディング処理」が 有用であるという発表であった。「ストリッピング補正」との違いに ついて質問があったが, 基本的には同様な方法であるとの回答であ つた。この報告は研究途上の中間報告であり, 研究の完成に期待し たい.

演題95は，1枚のアルミニウム板を傾斜させることによって，X 線の透過厚を連続的に変化させて半価層を測定するという発表で あった。ただ，対象装置が乳房撮影装置であることが原因と思われ る問題点も多く報告され，今後の解決に期待がもたれる.アルミニ ウムに拘る事なく，材質を検討し，いわゆる通常の半価首剆定を行 い, 今回の「傾斜法」と比較するのも興味ある課題であると考えら れる.今後の研究の発展に期待したい.

演題96は，現在, 照射線量で提供されている標準線量を, ICRU Slab Phantom で作成した自由空気外挿電離箱によって測定され た吸収線量に変更することができるという重要な発表であったが， スライドの字数が多かったことと, 発表が規定時間を越えたことに より会場と十分な討論ができなかったのは残念であった. 報告内容 が重要なだけに，発表方法を工夫し，十分な討論ができるようにす べきであった。論文化の準備ができているので，論文として投稿す るとのコメントがあった.

演題97は, 新素材のシンチレーションファイバーを使用した線量 計の開発に関する発表であった。現在, 演者らは CT 専用線量計の 開発を試みているが, 治療用線量計 (腔内用) への使用も可能であ ると考えられる。ささらに, シンチレーションであるからスペクトル の測定も可能ではないかの質問に対して, 現時点では検討していな いが，十分に可能であるとの回答であった、線量計の完成報告が待 たれる。

演題98は, 温泉水中のラドン222㵚度测定を, 自作のカクテルと市 販のカクテルで行い, その比較結果の発表であった. 内容は自作の カクテルの有用性を報告することにあったと思われるので，なぜ自 作カクテルを作成する必要があったのか, 市販カクテルとの使用 上・作成上の差異などに重点を置き, 報告を行えば内容が理解しや すく，素晴らしい発表になったと思われる。

MR 基礎- 2（演題番号99～102）

山田幸典（国立皅器器病センター） 当セッションは「MR 基礎- $2 」$ と題し 4 題の発表があった，演 題99は日本医大附属病院の土橋による, 高速 SE 法における metal artifact と磁化率効果をバンド幅を中心に SE 法と比較挨討した報 告であった。座長よりファントムに用いてある硫酸銅水溶液と塩化 ニッケル水溶夜の不統一の理由はとの質問があった。演者より，特 に意図はなく，手近のものを用いたとの回答があった。かなり詳細 な検討がなされていたが, 折角1.5Tと0.5Tの異なる磁場強度の装 置で測定しているのだから，その差異が結果に反映される検討がな されていれば，他施設での汎用性がより増したと思われる。また， 多くの検討すべき課題が演者により示された。これらの課題を演者 